\title{
Human Capital Requirement in Research for Enhancing Economic Development and Quality of Life
}

\author{
M. J. S. Wijeyaratne \\ Senior Professor and Chair of Zoology, University of Kelaniya, and \\ Chairman, National Science and Technology Commission of Sri Lanka
}

\section{Introduction}

It is well known that sustained economic development of any country depends on the availability of relevant human capital. At present we are living in an era of fourth industrial revolution which is characterized by interaction and amalgamation of several spheres, namely the physical, biological and cyber. Not like the other three revolutions, the fourth industrial revolution is taking place at an exponential rate thus affecting the industries in all countries. In order to stay competitive in the rapidly changing economically and technologically advancing environment, Sri Lanka needs sufficient amount of human capital capable of developing new technologies and innovations, and also managing them. Hence the availability of sufficient amount of human capital in Research and Development (R\&D) is of utmost importance.

A strong relationship between per capita GDP and the number of researchers in $R \& D$ in country has been observed ( $r=0.761 ; p=0.000)$, (Figure 01).

According to World Bank (2016 b), the number of researchers in R\&D in Sri Lanka is very much less than the world average (World Bank 2016 b) (Table 01). In addition, this number has decreased from 2000 to 2010 (Table 01). However according to NSF (2015) the number of R\&D personnel in Sri Lanka in 2010 is 5162, which is around 250 per million people. Nevertheless, it is less than the world average. 


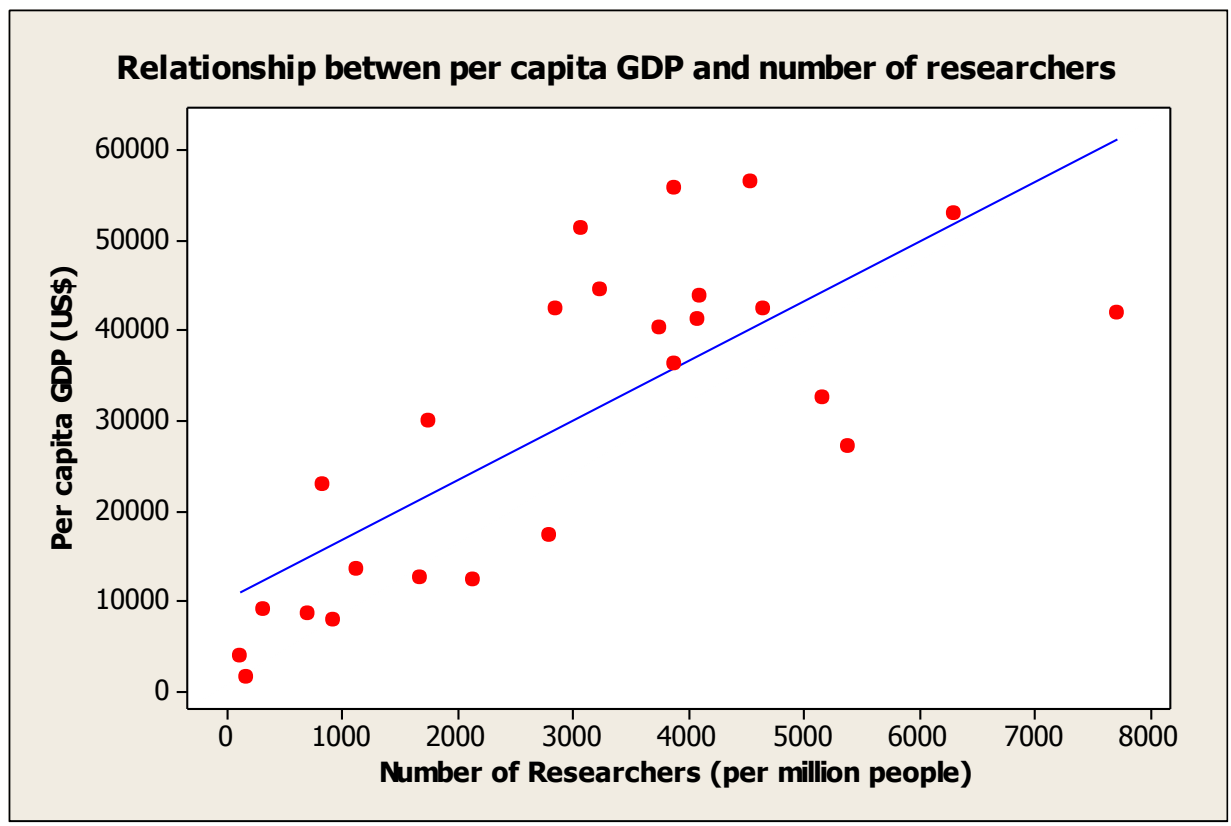

Figure 01: Relationship between per capita GDP and the number of researchers in $R \& D$ in different countries

Table 01: Number of R\&D personnel and the per capita GDP of some selected countries (Source World Bank 2016 a and 2016 b)

\begin{tabular}{|c|c|c|c|}
\hline \multirow[t]{2}{*}{ Country } & \multicolumn{2}{|c|}{$\begin{array}{l}\text { Number of R\&D personnel } \\
\text { (Per million people (Source } \\
\text { World Bank 2016 b) }\end{array}$} & \multirow{2}{*}{$\begin{array}{l}\text { Per capita GDP } \\
\text { (UD\$) in 2015 } \\
\text { (Source World } \\
\text { Bank 2016 a) }\end{array}$} \\
\hline & 2000 & 2010 & \\
\hline Argentina & 713 & 1121 & 13431 \\
\hline Australia & 3454 & 4531 & 56327 \\
\hline Belgium & 2974 & 3738 & 40231 \\
\hline Brazil & 420 & 698 & 8538 \\
\hline Canada & 3514 & 4649 & 42248 \\
\hline China & 547 & 908 & 7924 \\
\hline Cyprus & 301 & 820 & 22957 \\
\hline Czech Republic & 1350 & 2782 & 17321 \\
\hline Finland & 6732 & 7717 & 41920 \\
\hline France & 2897 & 3868 & 36248 \\
\hline Germany & 3149 & 4078 & 41219 \\
\hline
\end{tabular}




\begin{tabular}{|c|c|c|c|}
\hline \multirow[t]{2}{*}{ Country } & \multicolumn{2}{|c|}{$\begin{array}{l}\text { Number of R\&D personnel } \\
\text { (Per million people (Source } \\
\text { World Bank } 2016 \text { b) }\end{array}$} & \multirow{2}{*}{$\begin{array}{l}\text { Per capita GDP } \\
\text { (UD\$) in 2015 } \\
\text { (Source World } \\
\text { Bank 2016 a) }\end{array}$} \\
\hline & 2000 & 2010 & \\
\hline Hong Kong & 1139 & 2843 & 42422 \\
\hline Hungary & 1409 & 2131 & 12259 \\
\hline India & 110 & 157 & 1581 \\
\hline Ireland & 2217 & 3070 & 51289 \\
\hline Italy & 1157 & 1736 & 29847 \\
\hline Japan & 5151 & 5153 & 32477 \\
\hline Mexico & 216 & 312 & 9009 \\
\hline Netherlands & 2655 & 3229 & 44433 \\
\hline Poland & 1434 & 1672 & 12494 \\
\hline Republic of Korea & 2345 & 5380 & 27221 \\
\hline Singapore & 4245 & 6307 & 52888 \\
\hline Sri Lanka & 135 & 106 & 3926 \\
\hline United Kingdom & 2897 & 4091 & 43734 \\
\hline USA & 3476 & 3867 & 55836 \\
\hline World average & 1083 & 1284 & 9995 \\
\hline
\end{tabular}

\section{Required Number of Researchers}

It is evident from Figure 1 that increasing the number of $R \& D$ personnel is a vital requirement for increasing the GDP of a country. The UNESCO has determined the required number of R\&D personnel in each country for economic development. Accordingly, the number of R\&D personnel required by 2020 to enhance and sustain our economic development has been estimated as 20,000. As per NSF (2015), the number of R\&D personnel in Sri Lanka in 2013 is 5705, which is an increase of 543 since 2010 (Table 02). At this rate of increase, by 2020 there will be only 7205 R\&D personnel in Sri Lanka which is far below the required number. 
Table 02: Number of R\&D Personnel in Sri Lanka

\begin{tabular}{lll}
\hline Sector & $\mathbf{2 0 1 0}$ & $\mathbf{2 0 1 3}$ \\
\hline Higher education & 2315 & 2668 \\
State & 1673 & 1819 \\
Private and NGO & 1174 & 1218 \\
\hline Total & $\mathbf{5 1 6 2}$ & $\mathbf{5 7 0 5}$ \\
\hline
\end{tabular}

Source: NSF, 2015

According to Frascati Manual, a researcher is defined as "a professional engaged in the conception or creation of new knowledge, products, processes, methods and systems and also in the management of the projects concerned. Postgraduate students at the $\mathrm{PhD}$ level engaged in $\mathrm{R} \& \mathrm{D}$ are also considered as researchers" (OECD, 2002). All researchers are considered as R\&D personnel. Although postgraduate students at the $\mathrm{PhD}$ level are considered as Researchers, all researchers need not have a $\mathrm{PhD}$. This is evident from the educational qualifications of R\&D personnel stipulated in NSF (2015). Only about $28 \%$ of the R\&D personnel in Sri Lanka have PhDs (Table 03). The personnel even with a Bachelor's degree who conduct research in a professional manner or manage research and projects are considered as $\mathrm{R} \& \mathrm{D}$ personnel (NSF, 2015). Nevertheless, those who are not engaged in conducting or managing research are not considered as $\mathrm{R} \& \mathrm{D}$ personnel, even though they have a PhD.

Table 03: Educational Qualifications of R\&D Personnel in Sri Lanka in 2013

\begin{tabular}{lrr}
\hline \multicolumn{1}{c}{ Qualification } & Number & \multicolumn{1}{c}{$\%$} \\
\hline PhD & 1600 & 28 \\
MPhil/MSc & 836 & 15 \\
MD/MS & 579 & 10 \\
PG Diploma & 221 & 4 \\
BSc Honors & 1015 & 18 \\
BSc General & 685 & 12 \\
Other & 769 & 13 \\
\hline Total & $\mathbf{5 7 0 5}$ & $\mathbf{1 0 0}$ \\
\hline
\end{tabular}

Source: NSF, 2015 
About 19\% of R\&D personnel in Sri Lanka are from the fields outside science and technology (NSF, 2015) (Table 04).

Table 04: R\&D Personnel in Different Disciplines in 2013

\begin{tabular}{lrr}
\hline Discipline & Number & \% \\
\hline Natural Sciences & 1399 & 25 \\
Agricultural sciences & 1064 & 19 \\
Engineering and Technologies & 1158 & 20 \\
Medical Sciences & 976 & 17 \\
Social Sciences and Humanities & 707 & 12 \\
Other & 401 & 7 \\
\hline Total & $\mathbf{5 7 0 5}$ & $\mathbf{1 0 0}$ \\
\hline
\end{tabular}

Source: NSF, 2015

\section{The Way Forward}

Number of $\mathrm{PhD}$ students can be considered as a specific measure of the potential research capacity of a country as they will most probable get into a $\mathrm{R} \& \mathrm{D}$ career if opportunities are provided.

The number of $\mathrm{PhDs}$ produces by the Sri Lankan University system in the recent past is given in Table 4 (Source: UGC_2014, 2015, 2016). Only 244 $\mathrm{PhDs}$ have been produced during the past 3 years. However, an increasing trend has been observed in 2015 where $113 \mathrm{PhDs}$ have been produced. This is an increase by $70 \%$ as of the previous year. Of these 113 , the University of Kelaniya has produced the highest number, which is 21 , followed by the University of Sri Jayewardenepura (16), University of Colombo (14) and University of Jaffna (12). These four universities have contributed to $56 \%$ of the $\mathrm{PhDs}$ produced in the entire country. The postgraduate institutes have produced only $27 \mathrm{PhDs}$ (Postgraduate Institute of Agriculture -12; Postgraduate Institute of Pali and Buddhist Studies - 5; Postgraduate Institute of Archaeology - 4; Postgraduate Institute of Management - 2; and Postgraduate Institute of Humanities and Social Sciences -4), which is only about $24 \%$ of the total number produced.

Therefore, there is an urgent need to increase the number of $\mathrm{PhDs}$ produced from our university system. It is necessary to encourage the academics of our universities to produce more and more $\mathrm{PhDs}$ as the economic development of the country is dependent on the number of future researchers. This can be 
done by providing additional funding for the universities to carry out more research. It is encouraging that the Government had recently provided an additional grant of LKR 650 million to Sri Lankan Universities to conduct research in high thrust areas. However, for economic development, it is necessary to provide more funding for R\&D. In Sri Lanka only $0.11 \%$ of the GDP has been spent on R\&D (NSF 2016). In the developed countries it is more than $1 \%$ and in some SAARC countries it is more than ours (India $0.81 \%$; Pakistan - 0.33\%) (NSF 2016). It is expected that the government will provide more funding in the years to come. At the same, in the present context, it is necessary that the academic community utilize such funding in research which directly contribute to immediate economic development.

Table 04: Number of PhDs Produced by Sri Lankan Universities and Postgraduate Institutes from 2013 to 2015

\begin{tabular}{lr}
\hline Year & Number \\
\hline 2013 & 64 \\
2014 & 67 \\
2015 & 113 \\
\hline Total & $\mathbf{2 4 4}$ \\
\hline
\end{tabular}

Source: NSF, 2015

To encourage academics to produce more $\mathrm{PhDs}$, some financial benefits may also be provided to them depending on the number produced. In addition, qualified persons outside the university system should be encouraged to serve as co-supervisors of $\mathrm{PhD}$ students. Through such an initiative, physical resources which are available outside the universities could also be utilized for research, thus mitigating the financial constraints, especially in the fields of science, engineering and technology where large amount of money is needed to purchase the required equipment. The supervisors from outside the university system could be recognized by appointing them as adjunct professors on honorary capacity.

It is also necessary to attract the best students graduating with Bachelor's degrees to $\mathrm{PhD}$ studies. This can be done by providing them an attractive stipend similar to that of a probationary lecturer in the university system. 
Further, it is necessary to provide the $\mathrm{PhD}$ holders appropriate positions in the R\&D sector to harness their full potential.

\section{The National Research and Development Framework}

The National Science and Technology Commission of Sri Lanka (NASTEC), which is empowered by the Science and Technology Development Act No. 11 of 1994 to monitor the progress of projects and programmes in Science and Technology institutions in Sri Lanka has identified 10 focus areas where immediate attention is needed for rapid economic and social development. These 10 focus areas are Water; Food, agriculture and nutrition; Health; Shelter; Environment; Energy; Minerals; Apparel industry; ICT and knowledge service; and Basic sciences, emerging technologies and indigenous knowledge.

The R\&D interventions needed in these 10 focus areas have been identified in the National Research and Development Framework (NRDF), which has been approved by the Cabinet of Ministers. Development of human capital is one of the interventions needed in each of these focus areas. This human capital is needed for planning of R\&D activities, policy development and also in decision making. Hence in the management of human capital required in the 10 focus areas identified in the NRDF and approved by the Cabinet of Ministers is very much needed for enhancing economic development and quality of life of the people in Sri Lanka.

\section{References}

NSF (2015) Sri Lanka Science \& Technology Statistical Handbook 2013, National Science Foundation, Colombo, Sri Lanka. http://www.nsf.ac.lk/images/stories/STPRD/Handbook2013withCP.p df (Accessed on 13.10.2016).

OECD (2002) Frascati Manual 2002: Proposed Standard Practice for Surveys on Research and Experimental Development, The Measurement of Scientific and Technological Activities, OECD Paris. http://www.oecd-ilibrary.org/science-and-technology/frascatimanual-2002_9789264199040-en. (Accessed on 25.05.2013) 
UGC (2014) Sri Lanka University Statistics 2013, University Grants Commission, Colombo, Sri Lanka. http://www.ugc.ac.lk/en/publications/1418-sri-lanka-universitystatistics-2013.html (Accessed on 13.10.2016)

UGC (2015) Sri Lanka University Statistics 2014, University Grants Commission, Colombo, Sri Lanka. http://www.ugc.ac.lk/en/publications/1573-sri-lanka-universitystatics-.html (Accessed on 13.10.2016)

UGC (2016) Sri Lanka University Statistics 2015, University Grants Commission, Colombo, Sri Lanka. http://ugc.ac.lk/en/component/content/article/1709-sri-lankauniversity-statistics-2015.html (Accessed on 13.10.2016)

World Bank (2016 a) GDP per capita.

http://data.worldbank.org/indicator/NY.GDP.PCAP.CD (Accessed on 13.10.2016).

World Bank (2016 b) Researchers in R\&D.

http://data.worldbank.org/indicator/SP.POP.SCIE.RD.P6_(Accessed on 13.10.2016). 